MACIEJ DZIKUĆ

\title{
Environmental management with the use of LCA in the Polish energy system
}

Ph.D. Maciej Dzikuć University of Zielona Góra Faculty of Economics and Management

\section{Introduction}

Energy has significantly facilitated development of modern civilization. Energy security of many countries and regions relies on efficient functioning of energy system. Energy sector products greatly influence operations of all economy branches. The quality of fuel and energy produced in this branch along with their price and level and scope of services provided by energy enterprises are of particular importance for efficient management of entities conducting business activities.

Currently, economies of all highly developed countries are dependent from constant electricity supplies which is generated on the basis of traditional energy materials. In Poland, the share of energy carriers on the basis of which electricity is produced substantially differs from this structure in other countries. Nearly $90 \%$ of country electricity is generated with coal and lignite. Since the resources of energy raw supplies are limited and due to harmful emissions created in the process of burning, it is advisable to work towards reducing the use of traditional energy carriers. Decrease of the amount of coal burnt in electricity production will result in increasing the use of other sources, such as 
renewable energy sources, nuclear energy or natural gas, which emits far less pollution in burning than coal. However, the process of reducing the use of coal in the generation of electricity in Poland will be prolonged due to having our own this resource. Therefore, taking into account national coal resources and their significant share of the electricity generation environmental management should be carried out in such a way as to reduce the impact on the environment. Method that enables you to effectively evaluate and compare the impact of electricity generation on the environment is Life Cycle Assessment (LCA).

The aim of the study was to determine the impact on the environment occurring during the production of electricity in Dolna Odra (hard coal) and Turów Power Plant (lignite). The analysis also allowed LCA to compare the results.

In this article the following research hypothesis was formulated: Environmental impacts of energy production depends mainly on the fuel used in its manufacture. However the scale of energy production has no environmental impact of, assuming that it is analyzed in power plants of at least medium size.

The paper has been made to evaluate and compare the impact of electricity production in two large Polish coal-fired power plants. During the analysis the data from:

- Dolna Odra Power Plant which is a hard coal-fired,

- Turów Power Plant, in which electricity is produced by burning lignite.

\section{General presentation of Life Cycle Assessment}

LCA is a technique to evaluate environmental impacts, which creates possibilities for their identification, prioritization, and also allows consumers to make ecologically determined choices with a optimal impact on the environment (Menten, Chèze, Patouillard, Bouvart. 2013, pp. 108-134). LCA technique has been described by the International Committee for Standardization in the standards of the ISO 14040: PN-EN ISO 14040:2009 and PN-EN ISO 14044:2009. Life cycle assessment is a technique for assessing various aspects associated with development of a product and its potential impact throughout a product's life from raw material acquisition, processing, manufacturing, use and finally its disposal (Varun, Bhat, Prakash 2009, pp. 1067-1073; Malca, Coelho, Freire 2014, pp. 837-844; Dzikuć, Urban 2014, pp. 295-298; Dzikuć, Adamczyk 2015, pp. 217-225).

The International Organization for Standardization (ISO) adopted an environmental management standard as part of its 14,000 standards series, with the 14,040 series focusing on establishing methodologies for LCA. 
A similar approaches have been adopted by other international organizations (Dzikuć, Zarębska 2014, pp. 41-52; Cabeza, Rincón, Vilariño, Pérez, Castell 2014, pp. 394-416).

Life Cycle Assessment is a recognized research method, which allows the identification of environmental risks. LCA is based on the identification and determination of the amount consumed raw material, energy and waste products and pollutant emissions, and then assessing the impact of these elements on the environment (figure 1).

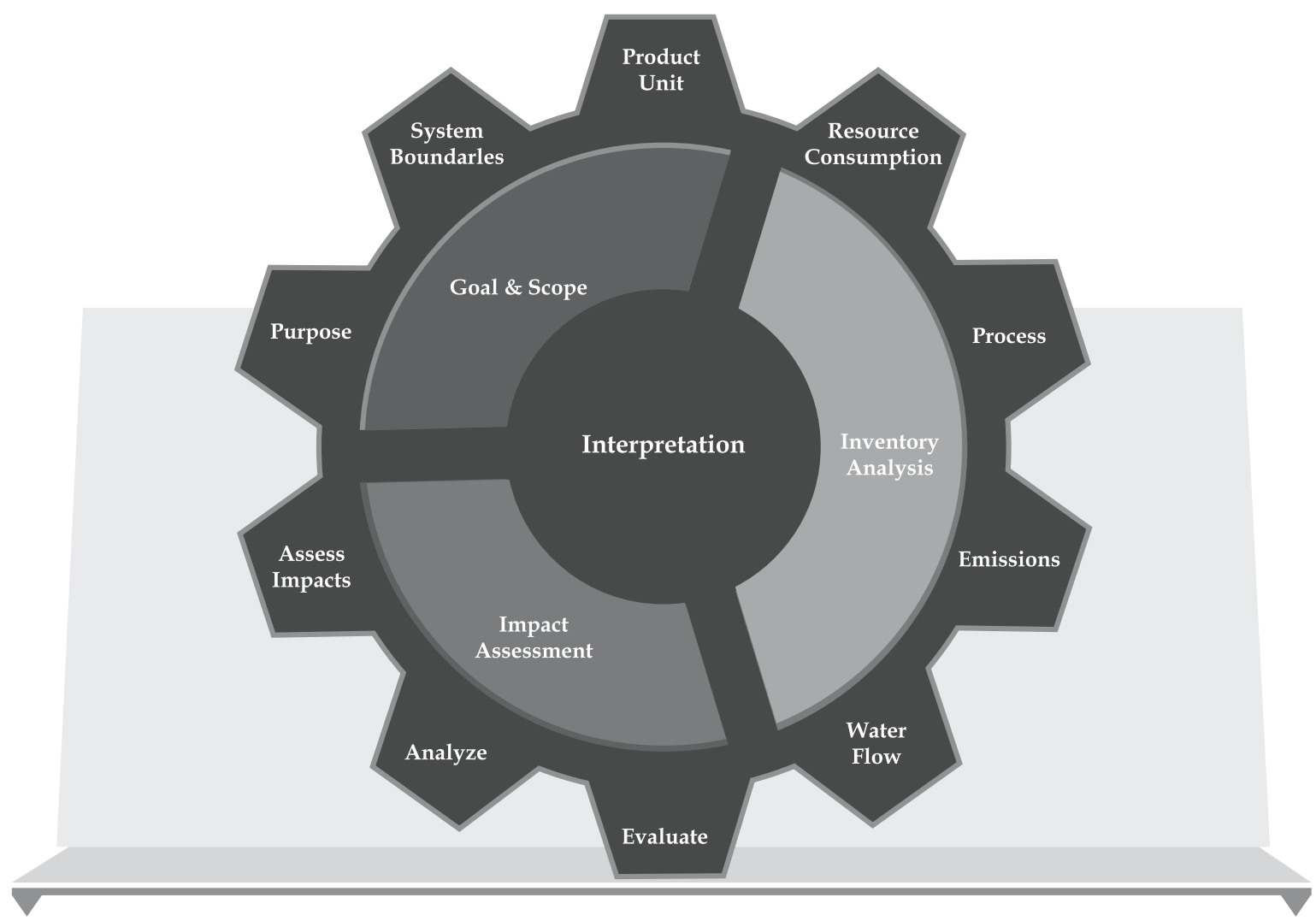

Figure 1. LCA Elements

Source: Thorn, Kraus, Parker 2011, pp. 1-10

The Life Cycle Assessment can be greatly simplified with the use of a dedicated computer software, such as SimaPro, designed by PRe Consultans B. V. designed at the Institute of Energy and Environmental Research in Heidelberg (Zarębska 2013, pp. 106-110). During the research used version 7.1 of SimaPro, which uses the Eco-indicator 99 in the process of the 
environmental analysis (Dąbrowski, Dzikuć 2012, pp. 819-821). This indicator has the advantage that it takes into account the diminishing resources problem, which is very important in an analysis of environmental impact of various energy generation methods, since energy generation requires the use of a great amount of non-renewable energy resources. As a functional unit during the research, which is a unit of reference describing the effect of the product the system adopted 1 MWh of electricity (Björklund 2011, pp. 82-87; Zarębska, Dzikuć 2013, pp. 97-102).

LCA method allows you to specify the least aggravating environmental technology at the design stage power plant. Information on the amount of emissions generated may prove crucial to the profitability of the investment due to rising $\mathrm{CO}_{2}$ emissions charges. The presentation of the result of environmental interference of electricity, as well as other products subject to the assessment, takes place in the form of $\mathrm{Pt}$ units (point of eco indicator), where 1 point of eco indicator $(\mathrm{Pt})$ is a value, which represents one thousandth of annual environment load of one citizen in Europe (Dzikuć, Piwowar 2013, pp. 382-392).

\section{The results of the LCA}

During the study Dolna Odra Power Plant and Turów Power Plant were used as an example. The data that were used to study come from 2012 and include the elements included in the system used in the production of electricity. The Turów Power Plant is a thermal power plant, a condensation block of intercooled reheat of steam and closed cooling water system. The share of power installed in the Turów Power Plant in the Polish energy system is about 7\%. The main fuel in the Turów Power Plant is lignite (Dzikuć, Dzikuć 2013, pp. 846-852). In 2012 in Turów Power Plant 11422485 MWh of energy were produced and the generation of electricity consumed $9886368 \mathrm{Mg}$ of lignite.

Dolna Odra Power Plant is a system power station which was built in the seventies of the twentieth century. The plant has eight blocks with a total capacity of $1772 \mathrm{MW}$ of electricity. It is a conventional block power plant with an open cooling system. The production of Dolna Odra Power Plant is intended for National Power System and for heat supply for the city of Gryfino. The core business of Dolna Odra Power Plant is the production and distribution of electricity and heat from hard coal (Adamczyk, Dzikuć 2014, pp. 42-50). In 2012 in Dolna Odra Power Plant 5503784 MWh of energy were produced and the generation of electricity consumed $2252722 \mathrm{Mg}$ of hard coal. (http://www. gkpge.pl/ 2015). 
Table 1. The LCA Results - the three damage categories (2012)

\begin{tabular}{c|c|c|c}
\hline Impact categories & Unit & Dolna Odra Power Plant & Turów Power Plant \\
\hline Resources & $\mathrm{Pt}$ & 25.0 & 17.8 \\
\hline Human health & $\mathrm{Pt}$ & 8.0 & 0.3 \\
\hline Ecosystem quality & $\mathrm{Pt}$ & 1.0 & $\mathbf{2 5 . 3}$ \\
\hline Total & $\mathrm{Pt}$ & $\mathbf{3 4 . 0}$ & 25 \\
\hline
\end{tabular}

Source: Dzikuć, Łasiński 2014, pp. 849-855, Dzikuć, Dzikuć 2013, pp. 846-852

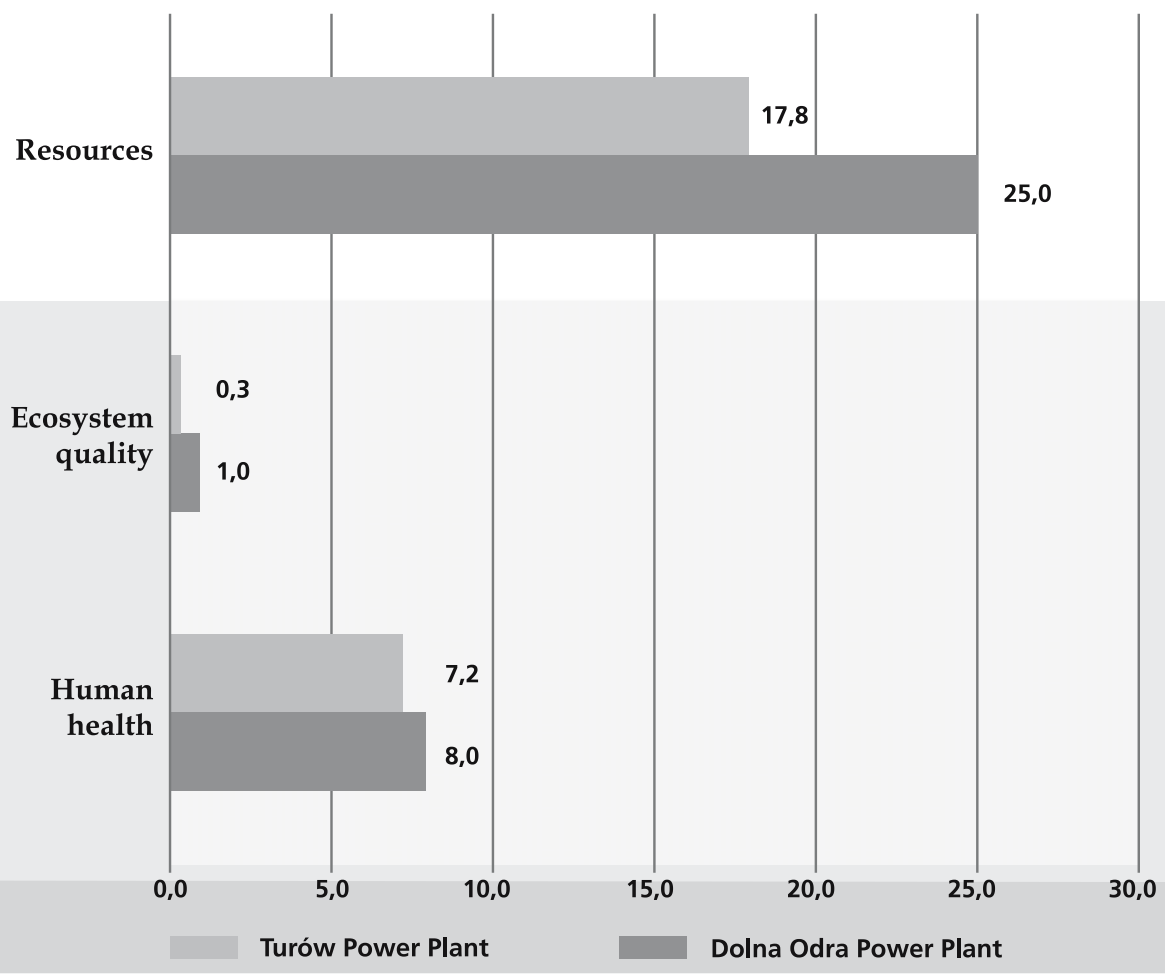

Figure 2. LCA Results in Pt- the three damage categories (data from 2012)

Source: Dzikuć, Łasiński 2014, pp. 849-855, Dzikuć, Dzikuć 2013, pp. 846-852

Analysis of the results of LCA in respect of the three categories of damage indicates that the greatest negative impact on the environment is characterized 
by the category of "raw materials". This influence can be seen in both the Turów Power Plant (lignite-fired) and Dolna Odra Power Plant (hard coal-fired). It should be noted, however, that the greater the impact on the environment is characterized by the generation of electricity from hard coal (figure 2 and table 1). This result is due to the smaller resources of hard coal in relation to lignite. Other factors negatively affecting the environment in relation to the three categories of damage categories are "human health" and "ecosystem quality". Also in the case of these categories of damage greater negative impact on the environment is the generation of electricity in Dolna Odra.

The research results should be compared with the results achieved by the Power Plant and Power Plant Dolna Odra Turów in 2010 (table 2). Conducted a series of investments in power plants resulted in a significant reduction of the negative impact on the environment. It should be noted that a much greater range of reduced environmental impact Turów Power Plant, which carried out a number of investment processes. The most important action that contributed to reducing the environmental impact of electricity generation in Turów Power Plant include:

- shutdown of power unit No. 8 in 2010,

- to increase the share of biomass, which is co-combustion of lignite during electricity production, co-firing of biomass contributes to reduce the consumption of lignite,

- commissioning of purification systems pollution emitted into the atmosphere,

- starting in Turów Power Plant for biomass combustion for power units 1, 2, 3 and 4 .

The energy production with help of currently used energy resources in Poland adversely affects the environment. However, this impact may be limited by using materials and technologies that less charge the environment. Life cycle assessment can effectively support the development of clean energy production. In addition, the hypothesis posed in the article was confirmed on the basis of data obtained from the Polish power plants that were analyzed by LCA.

Table 2. The LCA Results - the three damage categories (2010)

\begin{tabular}{c|c|c|c}
\hline Impact categories & Unit & Dolna Odra Power Plant & Turów Power Plant \\
\hline Resources & $\mathrm{Pt}$ & 27.0 & 19.9 \\
\hline Human health & $\mathrm{Pt}$ & 10.2 & 11.1 \\
\hline
\end{tabular}




\begin{tabular}{c|c|c|c} 
Ecosystem quality & $\mathrm{Pt}$ & 1.5 & 1.1 \\
\hline Total & $\mathrm{Pt}$ & 38.7 & 32.1 \\
\hline
\end{tabular}

Source: Dzikuć 2013, pp. 33-36

\section{Conclusion}

The studies conducted by the LCA show that the negative environmental impacts of electricity generation is dependent mainly on the fuel used in its manufacture. But the scale of energy production has no significant environmental effect, assuming it is analyzed in power plants of at least medium size.

In Poland, nearly $90 \%$ of the electricity is produced using coal. The use of indigenous energy resources is economically justified. However, it is necessary to search for solutions that will reduce greenhouse gas emissions to the atmosphere.

Analysis of environmental loads carried out in the article indicates that you should look for solutions that are less harmful to the environment. Not only for environmental reasons but also for economic reasons. Companies that produce electricity in Poland are obliged to pay for greenhouse gas emissions into the atmosphere. The existing energy infrastructure in Poland helps reduce the negative impact on the environment. Through the use of co-firing biomass with coal is possible to reduce the negative impact on the environment. Biomass is a relatively inexpensive fuel, and therefore does not increase significantly the price of electricity.

\section{Summary}

Environmental management with the use of LCA in the Polish energy system

The article presents an assessment of the Life Cycle Assessment (LCA) and pointed out its advantages in the analysis of the environmental impact of electricity generation. The article also points to the direction of development of the Polish energy sector and pointed out the need to determine the environmental risks associated with the production of electricity. The use of coal and lignite as the primary fuel causes a significant burden on the environment. An analysis by the method of LCA based on data 
obtained from two Polish power plants. The results were compared and identified the cause of the existing differences in the results obtained. The article sets out the actions that contributed to reduce the negative impact on the environment, taking place during the production of electricity.

Keywords: Life Cycle Assessment, electricity, ecology, coal power plants.

\section{Streszczenie}

Zarządzanie środowiskowe $\mathrm{z}$ wykorzystaniem analizy LCA $\mathrm{w}$ polskim systemie energetycznym

W artykule przedstawiono ocenę cyklu życia (Life Cycle Assessment - LCA) oraz wskazano na jej zalety podczas analizy wpływu na środowisko wytwarzania energii elektrycznej. W artykule wskazano również na kierunki rozwoju polskiego sektora energetycznego oraz wskazano na konieczność określania zagrożeń środowiskowych związanych $\mathrm{z}$ wytwarzaniem energii elektrycznej. Wykorzystanie węgla kamiennego oraz brunatnego jako podstawowego paliwa powoduje znaczne obciążenie środowiska. Przeprowadzono również analizę za pomocą metody LCA na podstawie danych uzyskanych z dwóch polskich elektrowni. Wyniki badań porównano oraz wskazano na przyczynę występujących różnic $\mathrm{w}$ osiągniętych wynikach. W artykule określono działania, które przyczyniły się do zmniejszenia negatywnego wpływu na środowisko, mającego miejsce podczas wytwarzania energii elektrycznej.

\section{Słowa}

kluczowe: ocena cyklu życia, energia elektryczna, ekologia, węgiel, elektrownie.

\section{References}

1. Adamczyk J., Dzikuć M. (2014), The analysis of suppositions included in the Polish Energetic Policy using LCA technique - Poland case study, Renewable and Sustainable Energy Reviews, Vol. 39.

2. Björklund A. (2012), Life cycle assessment as an analytical tool in strategic environmental assessment. Lessons learned from a case study on municipal energy planning in Sweden, Environmental Impact Assessment Review, Vol. 32. 
3. Cabeza L. F., Rincón L., Vilariño V., Pérez G., Castell A. (2014), Life cycle assessment (LCA) and life cycle energy analysis (LCEA) of buildings and the building sector: A review, Renewable and Sustainable Energy Reviews Vol. 29.

4. Dąbrowski R., Dzikuć M. (2012), Life Cycle Assessment in energy sector, Measurement Automation and Monitoring Vol. 58, no. 9.

5. Dzikuć M. (2013), Zastosowanie analizy cyklu życia (LCA) do oceny wptywu wytwarzania energii elektrycznej na środowisko, Przegląd Elektrotechniczny, no. 4.

6. Dzikuć M., Adamczyk J. (2015), The ecological and economic aspects of a low emission limitation: a case study for Poland, International Journal of Life Cycle Assessment, Vol. 20, no. 2.

7. Dzikuć M., Dzikuć M. (2013), Determining the environmental and economic benefits of life cycle assessment on example of the power plants in Poland, Chinese Business Review, Vol. 12, no. 12.

8. Dzikuć M., Łasiński K. (2014), Technical and economisc aspects of biomass cofiring in coal-fired boilers, International Journal of Applied Mechanics and Engineering, Vol. 19, no. 4.

9. Dzikuć M., Piwowar A. (2013), LCA analysis as a tool to assess the impact of electricity production on the environment, Management, Vol. 17, no. 1.

10. Dzikuć M., Urban S. (2014), The environmental impact assessment of thermal energy production in selected power plants, Energetyka. Electric Power \& Economy, no. 5.

11. Dzikuć M., Zarębska J. (2014), Analiza porównawcza produkcji energii w Elektrocieptowni Legnica i Elektrocieptowni Lubin z wykorzystaniem metody LCA, Polityka Energetyczna, Vol. 17.

12. http://www.gkpge.pl/ (10.02.2015 - date of access).

13. Malca J., Coelho A., Freire F. (2014), Environmental life-cycle assessment of rapeseed-based biodiesel: Alternative cultivation systems and locations, Applied Energy Vol. 114.

14. Menten F., Chèze B., Patouillard L., Bouvart F. (2013), A review of LCA greenhouse gas emissions results for advanced biofuels: The use of meta-regression analysis, Renewable and Sustainable Energy Reviews, Vol. 26.

15. Thorn M. J., Kraus J. L., Parker D. R. (2011), LCA Elements Life-Cycle Assessment as a Sustainability Management Tool: Strengths, Weaknesses, and Other Considerations, Environmental Quality Management, Vol. 20, no 3.

16. Varun, Bhat I. K., Prakash R. (2009), LCA of renewable energy for electricity generation systems- $A$ review, Renewable and Sustainable Energy Reviews, Vol. 13.

17. Zarębska J. (2013), Ekologiczne i ekonomiczne aspekty gospodarki odpadami opakowaniowymi w województwie lubuskim, Oficyna Wydawnicza Uniwersytetu Zielonogórskiego, Zielona Góra.

18. Zarębska J., Dzikuć M. (2013), Determining the environmental benefits of life cycle assessment (LCA) on example of the power industry, Scientific Journals Maritime University of Szczecin Vol. 34. 